\title{
$12: 54760154-54782854$
}

National Cancer Institute

\section{Source}

National Cancer Institute. 12:54760154-54782854. NCI Thesaurus. Code C42205.

Physical location of ERBB3_Gene 